\title{
Razlike v plačah in zaposlovanju med spoloma v dejavnostih javne uprave
}

UDK 35.088(497.12)

\author{
Janko Seljak \\ Fakulteta za upravo \\ janko.seljak@fu.uni-lj.si
}

\section{IZVLEČEK}

Glavni namen analize v tem članku je bil ugotoviti, ali (in kako) se kažejo razlike pri obravnavanju moških in žensk $v$ javni upravi oz. ali lahko ugotovimo manjšo diskriminacijo zaposlenih žensk v javni upravi kot v celotnem gospodarstvu. Analiza podatkov za Slovenijo je pokazala, da ženske $z$ visoko izobrazbo, magisterijem ali doktoratom $v$ javni upravi lažje dobijo zaposlitev, veliko težje pa dobijo ustrezno delovno mesto, na katerem je zahtevana ta stopnja strokovne usposobljenosti. Vendar se je stanje $\mathbf{v}$ zadnjih štirih letih pri mestih, "ki niso čisto na vrhu" (visoka usposobljenost, magisterij), že bistveno izboljšalo. Na področju plač je diskriminacija žensk $z$ visoko strokovno usposobljenostjo (vključno $z$ doktoratom in magisterijem) $v$ javni upravi veliko manjša, med ženskami $s$ srednjo in višjo izobrazbo pa večja kot med vsemi zaposlenimi. Ženske $z$ visoko izobrazbo so $v$ javni upravi nedvomno manj diskriminirane kot tiste s srednjo in višjo.

Ključne besede: javna uprava, javni sektor, razlike, plače, diskriminacija, spol, Slovenija.

\section{Diskriminacija na delovnem mestu}

Diskriminacija na delovnem mestu in v poklicu je različno in manj ugodno obravnavanje ljudi zaradi posameznih lastnosti, kot so spol, barva kože, vera, politična pripadnost ali socialni izvor, ne glede na njihov prispevek ali zahteve dela (ILO, 2003, str. 15). Dojemanja teh lastnosti in z njimi povezani stereotipi so pod močnimi vplivi zgodovine, ekonomske in družbene situacije, političnega režima in kulturnih razmer $\vee$ posamezni državi. Diskriminacija omejuje svobodo posameznika v pridobivanju dela, ki ga želi. Omejuje posameznike pri razvijanju njihovih potencialov, sposobnosti in talentov ter onemogoča, da bi bili nagrajeni v skladu s svojimi prispevki.

Po mnenju avtorjev zadnjega poročila Mednarodnega urada za delo (ILO) se je mednarodna skupnost sporazumela, da je treba odpraviti diskriminacijo, uveljaviti enakost $v$ svetu dela in preučiti dejavnike, ki lahko prispevajo k pospeševanju tega procesa (ILO, 2003 , str. 7). Ideja ni nova; namen zagotoviti enako plačilo za enako delo je bil zapisan že $v$ ustanovni listini ILO. Med vsemi vrstami diskriminacije na delovnem mestu je bila po 2. svetovni vojni najbolj raziskana diskriminacija ženske delovne sile. Ta naj bi zaradi druge svetovne vojne postala še izrazitejša: med vojno je bila večina moških $v$ vojski, 
zato so večino del opravile ženske. Ko so se moški vrnili iz vojne, je prisotnost žensk na trgu delovne sile ogrožala zaposlovanje moških in zniževala kakovost delovnih razmer.

Leta 1949 je bila v okviru ILO sprejeta konvencija, ${ }^{2}$ ki je potrdila pomembnost enakosti med moškimi in ženskami. $V$ njej je bila poudarjena pravica do enakega plačila "za delo enake vrednosti". S tem naj bi se odpravile neenakosti, ki so rezultat strukture trga dela: večina žensk opravlja slabše plačane poklice. To načelo je bilo še bolj poudarjeno $v$ direktivi EU o enakem plačilu 3 leta 1975 in v konvenciji ZN o odstranitvi vseh oblik diskriminacije žensk ${ }^{\mathbf{4}}$ leta 1979.

Razlogi za te dejavnosti niso bili samo $\vee$ želji zagotovitvi enake pravice za vse, temveč je ideja o izkoriščenosti vseh potencialov v samem središču ekonomskih teorij. $\checkmark$ skladu z neoklasično ekonomijo je lahko diskriminacija na delovnem mestu le kratkoročna, ker je draga in neučinkovita. Podjetniki, ki različno obravnavajo svoje delavce zaradi njihovega spola, rase ipd., naj bi propadli, saj manj učinkovito izrabljajo potenciale svojih zaposlenih, kot drugi, ki tega ne počno. Enakost v zaposlovanju in poklicu je tudi družbeno koristna in je pomemben del svobode, dostojanstva in blaginje posameznika. Stres, nizka morala in pomanjkanje motivacije so glavne posledice neenakosti. To pa ne vpliva slabo samo na počutje posameznikov, ampak tudi na njihovo produktivnost. Delavci, ki so obravnavani pošteno in jih pri delu spodbujamo, delajo z večjo pripadnostjo podjetju in $v$ večjo korist organizacije.

Seveda pa diskriminacija na delovnem mestu obstaja. Teorije, ki jo skušajo pojasniti, lahko uvrstimo $v$ dve veliki skupini: teorije investicij $\vee$ človeški kapital in diskriminacije na trgu dela.

Model človeškega kapitala pojasnjuje razlike $\vee$ plačah kot posledico razlik $\vee$ produktivnosti, ki so rezultat tradicionalne delitve dela $\vee$ družini. Zaradi tradicionalne vloge $\checkmark$ družini imajo ženske krajšo delovno dobo z več prekinitvami. So manj motivirane za investicije $\vee$ človeški kapital (formalno izobrazbo in izobraževanje na delovnem mestu). Posledica tega je tudi, da ženske izbirajo poklice, kjer so takšne investicije manj pomembne in kjer so "znižanja" plač zaradi prekinitve delovnega razmerja manjša. Posebej je to značilno pri poklicih, ki zahtevajo visoke investicije v zelo specifična znanja tako s strani podjetij kakor zaposlenih. Ta model pojasni manjši zaslužek žensk in tudi, zakaj je več žensk v poklicnih skupinah z nižjimi plačami.

Kljub razmeroma logični razlagi $v$ modelu človeškega kapitala pogosto ostane velik del razlik v plačah in položaju moških in žensk nepojasnjen. Baker (v Blau, Kahn, 1999) je razvil koncept diskriminacije na trgu dela. Diskriminacija naj bi bila posledica predsodkov o članih določenih skupin. Ta model gradi na teoriji nepopolnih informacij in na razlikah med skupinami pri pričakovani produktivnosti. To je t. i. teorija statistične diskriminacije, ki pravi, da delodajalci nimajo dovolj informacij o produktivnosti posameznih delavcev, saj ne morejo natančno preučiti njihovih sposobnosti. Poledica pomanjkanja informacij je, da svoje odločitve sprejemajo na osnovi lahko ugotovljivih

2 International Labour Organization: Convention No. 100, (navedeno v ILO, 2003, str. 9). 3 Council of the European Communities: Council Directive 75/117/ECC, 10. februar 1975.

4 United Nations: Convention on the Elimination of All Forms of Discrimination against Woman, UN: New York 1979. 


\section{Janko Seljak \\ Razlike $v$ plačah in zaposlovanju med spoloma v dejavnostih javne uprave}

značilnosti (npr. spola, rase), ki naj bi bile kazalec produktivnosti. To pomeni, da predpostavljajo, da lahko od pripadnikov posameznih skupin (npr. žensk, Romov) pričakujejo nižjo produktivnost kot od drugih. Zato se na osnovi predsodkov odločijo, da je stopnja tveganja napačne odločitve manjša, če zaposlijo moškega, kot če zaposlijo žensko.

Obstaja razmeroma malo kazalcev, ki bi neposredno kazali obstoj diskriminacije. Običajno se uporablja štiri skupine nadomestnih kazalcev, ki naj bi merili:

- diskriminacijo pri vstopu na trg dela;

- diskriminacijo, ki se kaže v strukturi brezposelnosti;

- diskriminacijo pri nagrajevanju;

- diskriminacijo pri vrsti dela, ki ga opravljajo moški in ženske.

Glavni namen analize $v$ tem članku je ugotoviti, ali (in kako) se kažejo razlike pri obravnavanju moških in žensk $v$ javni upravi oz. ali lahko na osnovi uporabljenih kazalcev ugotovimo manjšo stopnjo diskriminacije zaposlenih žensk $\vee$ javni upravi kot $\vee$ celotnem gospodarstvu. Država naj bi bila prva, ki bi zagotavljala spoštovanje ustave in zakonov, v katerih je nesporno vsakemu državljanu zagotovljena svoboda dela, prosta izbira zaposlitve in dostopnost do vseh delovnih mest pod enakimi pogoji. Torej mora zagotoviti tudi enako možnost dostopa do delovnih mest in enakega nagrajevanja pri zaposlitvah v javni upravi, kjer nastopa kot delodajalec. $V$ skladu s to nalogo bo analiza usmerjena na dve področji, ki pa bistveno vplivata tudi na vsa druga. Najprej bo na podlagi podatkov o strukturi zaposlenih po strokovni izobrazbi in usposobljenosti prikazano, kolikšen delež zaposlenih $\vee$ posameznih skupinah predstavljajo ženske in kakšne so bile spremembe $v$ zadnjih štirih letih (pravica do enakega dostopa vseh do delovnih mest $v$ javni upravi). Ta analiza bo $v$ drugem delu naloge dopolnjena s prikazom razmerij plač med moškimi in ženskami (pravica do enake nagrade za delo enake vrednosti).

\section{Zaposleni v javni upravi in njihove plače}

$\checkmark$ tem članku bo osnovna skupina preučevanja zaposleni $\vee$ javni upravi. Obstaja več načinov in ravni opredelitve dejavnosti, vezanih na tisti del družbenega življenja, ki ne spada v skupino zasebnega sektorja (podrobneje $v$ Seljak, 2000). Takšen pluralizem mnenj (oz. definicij) je na teoretično-analitični ravni sprejemljiv in $\vee$ nekaterih primerih tudi koristen, na zgodovinsko-konkretni ravni oz. pri praktičnem opredeljevanju pa povzroča vrsto problemov. Na praktični ravni opredeljevanja je treba razmejiti, ali posamezna organizacija sodi v okvir javne uprave, ali posamezno osebo lahko imenujemo delavec $\vee$ javni upravi itd. $\vee$ takšnih primerih običajno vstopi statistika s svojimi klasifikacijami. Ena od glavnih je enotna klasifikacije dejavnosti. $\vee$ novejšem času se $\vee$ Sloveniji uporablja Standardna klasifikacija dejavnosti, ki je mednarodno primerljiva z ISIC-3 in NACE, standardnima klasifikacijama dejavnosti Mednarodne organizacije dela in EU. V teh klasifikacijah je dejavnost, ki je najbližja teoretični opredelitvi javne uprave, označena s šifro L. $V$ to dejavnost spadajo:

- dejavnost javne uprave ter ekonomska in socialna politika skupnosti;

- zunanje zadeve; 
- obramba;

- pravosodje;

- javna varnost, zakonitost in red;

- zaščita in reševanje pri požarih in nesrečah;

- obvezno socialno zavarovanje.

Zaradi večje preglednosti in lažjega razumevanja bodo $v$ nadaljevanju vse zgoraj naštete dejavnosti poimenovane javna uprava (kar je v bistvu v skladu z definicijo “ožje javne uprave").

Tabela 1: Zaposlene osebe v družbah, podjetjih in organizacijah v Sloveniji in v javni upravi konec leta

\begin{tabular}{|c|c|c|c|c|c|}
\hline \multirow{2}{*}{ leto } & \multicolumn{2}{|c|}{ število zaposlenih v 1000} & \multirow{2}{*}{$\begin{array}{c}\% \text { v javni } \\
\text { upravi }\end{array}$} & skupaj & javna uprava \\
\hline & vsi zaposleni & javna uprava & & \multicolumn{2}{|c|}{$1993=100$} \\
\hline 1993 & 663,4 & 35,1 & 5,3 & 100,0 & 100,0 \\
\hline 1994 & 647,1 & 37,0 & 5,7 & 97,5 & 105,4 \\
\hline 1995 & 641,4 & 38,5 & 6,0 & 96,7 & 109,7 \\
\hline 1996 & 635,2 & 40,4 & 6,4 & 95,7 & 115,1 \\
\hline 1997 & 634,0 & 42,3 & 6,7 & 95,6 & 120,5 \\
\hline 1998 & 629,8 & 41,7 & 6,6 & 94,9 & 118,8 \\
\hline 1999 & 639,9 & 42,0 & 6,6 & 96,5 & 119,7 \\
\hline 2000 & 650,7 & 44,1 & 6,8 & 98,1 & 125,6 \\
\hline 2001 & 652,0 & 45,4 & 7,0 & 98,3 & 129,3 \\
\hline
\end{tabular}

Vir: SURS, 2002, str. 231; SURS, 2001, str. 248; SURS, 2000, str. 244; SURS, 1998, str. 223; SURS, 1996, str. 197.

Zniževanje skupnega števila zaposlenih $\vee$ celotnem gospodarstvu $\vee$ letih 19931998 je posledica krize nekaterih delovno intenzivnih panog in posledično prestrukturiranja slovenskega gospodarstva. Naraščanje števila zaposlenih $\vee$ javni upravi $\vee$ letih 1993-1996 naj bi bilo posledica novih nalog javne uprave zaradi vzpostavitve neodvisnosti in vključevanja v mednarodne organizacije. V letih 1997-1999 se je število zaposlenih ustalilo, $v$ zadnjih dveh letih pa je zopet očitno povečevanje, kar je posledica priprave Slovenije za vključitev v Evropsko unijo ${ }^{\mathbf{5}}$ oz. ustanavljanja novih institucij, ki jih zahteva ta proces. Zaposleni $\vee$ javni upravi so velik del zaposlenih $\vee$ Sloveniji: leta 1993 so zajemali 5,3\%, leta 2001 pa že $7 \%$ vseh zaposlenih.

Naslednja kategorija, ki bo pogosto uporabljena $\vee$ tem članku in jo je zato treba natančneje opredeliti, je brutoplača. Brutoplače so izplačani prejemki zaposlenih oseb za delo $v$ polnem delovnem času in času, krajšem ali daljšem od polnega delovnega časa. Poleg prejemkov za delo v rednem delovnem času zajemajo tudi vse druge prejemke, ki se oblikujejo na tej osnovi: nadure, nadomestila za letni dopust, plačani dopust do 7 dni, državne praznike, izostanke zaradi bolezni do 30 dni, za strokovno izobraževanje ipd.

5 Mihelčič (2003) meni, da služi večanje števila zaposlenih v javni upravi vladam držav:

- kot blažilnik nezaposlenosti v zasebnem sektorju;

- kot primerno področje za dokazovanje moči strank na oblasti. 


\section{Janko Seljak \\ Razlike v plačah in zaposlovanju med spoloma v dejavnostih javne uprave}

Brutoplače ne vsebujejo nadomestil, ki ne bremenijo podjetja oz. organizacije: nadomestil porodniške odsotnosti, bolniških odsotnosti, daljših od 30 dni, pripravništva, povračila stroškov za prevoz na delo in z dela, nadomestila za prehrano, za službena potovanja, izplačil za avtorske honorarje, regresa ipd. (SURS, 2002, str. 247).

Tabela 2: Povprečna mesečna brutoplača za zaposleno osebo v družbah, podjetjih in organizacijah po področjih dejavnosti 1993-2000

\begin{tabular}{|c|c|c|c|c|c|}
\hline \multirow{2}{*}{ leto } & vsi zaposleni & javna uprava & skupaj & javna uprava & \multirow{2}{*}{$\begin{array}{c}\text { indeks } \\
\text { povprečje }= \\
100\end{array}$} \\
\hline & \multicolumn{2}{|c|}{ v 1000 SIT } & \multicolumn{2}{|c|}{ indeks $1993=100$} & \\
\hline 1993 & 79,0 & 108,7 & 100,0 & 100,0 & 137,6 \\
\hline 1994 & 97,0 & 128,0 & 122,8 & 117,8 & 132,0 \\
\hline 1995 & 115,5 & 148,5 & 146,2 & 136,6 & 128,6 \\
\hline 1996 & 134,9 & 172,2 & 170,8 & 158,4 & 127,7 \\
\hline 1997 & 150,3 & 192,7 & 190,2 & 177,2 & 128,2 \\
\hline 1998 & 164,8 & 205,8 & 208,6 & 189,3 & 124,8 \\
\hline 1999 & 176,1 & 223,1 & 222,9 & 205,2 & 126,7 \\
\hline 2000 & 202,9 & 250,4 & 256,8 & 230,4 & 123,4 \\
\hline
\end{tabular}

Vir: SURS, 2002, str. 256; SURS, 2001, str. 262; SURS, 2000, str. 263; SURS, 1998, str. 243; SURS, 1996, str. 215.

Brutoplače so bile $v$ dejavnostih javne uprave, obrambe in socialnega zavarovanja vseskozi višje kot $v$ povprečju $v$ celotnem gospodarstvu. To je glede na izobrazbeno strukturo zaposlenih tudi pričakovano. Vendar so se $v$ obdobju 1993-2000 plače $v$ celotnem gospodarstvu povečevale hitreje kot $v$ dejavnosti javne uprave, obrambe in socialnega zavarovanja. Tako je znašala razlika leta 1993 37,6 \%, 2000 pa le še 23,4 \%. Vendar so povprečja $v$ primerih, ko opazujemo dve tako različni populaciji (glede na izobrazbeno strukturo), lahko zavajajoča. Nujno je, da analizo razdelimo vsaj na izobrazbene razrede (podrobneje $\vee$ Seljak, 2000).

\section{Zaposlene ženske v javni upravi}

V Sloveniji je bilo konec leta 2001 zaposlenih približno 309.000 žensk, od tega $\vee$ javni upravi 22.000 oz. 7,3 \% vseh zaposlenih žensk. Približno ena tretjina žensk v javni upravi je imela visoko izobrazbo, polovica pa srednjo ali manj od srednje. Izobrazbena struktura je bila boljša kot pri moških in boljša kot med vsemi zaposlenimi ženskami.

Delež žensk med vsemi zaposlenimi se je v opazovanem obdobju vseskozi manjšal, $v$ javni upravi pa se je do leta 1997 zviševal, potem pa nekoliko padel. V začetku obdobja je bil delež žensk $v$ javni upravi manjši kot $v$ celotnem gospodarstvu, po letu 1997 pa je večji. To gre pripisati relativno hitremu padanju števila zaposlenih žensk $v$ celotnem gospodarstvu. $\vee$ opazovanem obdobju se je pokazala kriza predvsem $\checkmark$ nekaterih dejavnostih, kjer so pretežno zaposlene ženske. $\vee$ proizvodnji tekstilij, tekstilnih in krznenih izdelkov, kjer je bilo v letu 1998 med zaposlenimi 78 \% žensk, se je $\vee$ letih 1994-1998 zmanjšalo število zaposlenih za skoraj 10.800. Podobno je 
bilo $v$ proizvodnji usnja in usnjenih izdelkov. Skupno število zaposlenih žensk se je zmanjševalo hitreje kot skupno število zaposlenih, $v$ javni upravi pa se je povečevalo tako skupno število zaposlenih kakor tudi število zaposlenih žensk.

Tabela 3: Zaposleni v družbah, podjetjih in organizacijah po področjih dejavnosti 1994-2000 - letno povprečje

\begin{tabular}{|c|c|c|}
\hline leto & $\begin{array}{c}\text { \% žensk med vsemi zaposlenimi } \\
\text { v celotnem gospodarstvu }\end{array}$ & $\begin{array}{c}\text { \% žensk med vsemi zaposlenimi } \\
\text { v javni upravi }\end{array}$ \\
\hline $\mathbf{1 9 9 4}$ & 48,7 & 48,3 \\
$\mathbf{1 9 9 5}$ & 48,9 & 47,9 \\
$\mathbf{1 9 9 6}$ & 48,8 & 48,7 \\
$\mathbf{1 9 9 7}$ & 48,1 & 49,9 \\
$\mathbf{1 9 9 8}$ & 47,9 & 48,5 \\
$\mathbf{1 9 9 9}$ & 47,6 & 48,8 \\
$\mathbf{2 0 0 0}$ & 47,6 & 49,0 \\
$\mathbf{2 0 0 1}$ & 47,4 & 49,0 \\
\hline
\end{tabular}

Vir: SURS, 2002, str. 256; SURS, 2001, str. 248, SURS, 2000, str. 244, SURS, 1998, str. 223, SURS, 1996, str. 197.

Vprašanje je tudi, na osnovi katerega kriterija lahko postavimo želeno strukturo zaposlenih. Ali je to 50 \% žensk, 50 \% moških? Ali je to delež žensk v skupnem številu prebivalcev (v Sloveniji $51 \%$ ) ali med aktivnimi prebivalci (v Sloveniji $46 \%$ )? Ob pomanjkanju absolutnih kriterijev uporabljamo relativne primerjave med državami. Primerljive podatke o deležu žensk med vsemi zaposlenimi zbirajo v večini držav, manj je primerljivih podatkov o spolni strukturi zaposlenih $\vee$ javni upravi. Vendar so vsaj za večino evropskih držav podatki zbrani po enakih kriterijih in nam razmerja med državami nedvomno podajo ustrezno informacijo o tem, kako država s svojo politiko spodbuja enak dostop do delovnih mest $v$ javni upravi.

Slovenija je s skandinavskimi državami in državami bivšega "socialističnega bloka" v skupini držav, ki imajo največji delež zaposlenih žensk $\vee$ javni upravi. $\vee$ tej skupini je še Francija. Najmanjši delež zaposlenih žensk imajo sredozemske države, kjer so tradicionalni vzorci obnašanja še zelo močni.

Delež žensk med zaposlenimi se $\vee$ večini držav vseskozi povečuje in je $\vee$ razvitih državah 35-50 \%. V vseh državah se pojavlja problem t. i. "poklicne segregacije" žensk. "Ženski poklici" so običajno manj zanimivi, slabše plačani, z nižjim statusom in manjšimi možnostmi napredovanja. Segregacija naj bi bila rezultat:

- družbenih norm in stereotipov (družinsko in poklicno življenje),

- izobrazbe in poklicnega izobraževanja,

- obdavčitve in sistema socialne varnosti,

- strukture trga dela, obsega sive ekonomije,

- diskriminacije pri vstopu na trg dela.

Značilnosti poklicev $v$ celotnem gospodarstvu se med seboj zelo razlikujejo in možnost nastanka tovrstnih nepravilnosti je večja. Poklici znotraj posamezne dejavnosti 


\section{Janko Seljak \\ Razlike v plačah in zaposlovanju med spoloma v dejavnostih javne uprave}

naj bi bili bolj homogeni. Posebej to velja za javno upravo, kjer naj bi država s svojimi posegi zmanjševala možnost tovrstnih ločevanj (moški, ženski poklici) oz. nudila možnost enakega dostopa do delovnih mest tako moškim kot ženskam. Odstotek žensk med vsemi zaposlenimi je sicer pomemben kazalec tovrstne enakopravnosti, vendar ga je treba dopolniti vsaj s primerjavo po stopnji strokovne izobrazbe in strokovne usposobljenosti.

Tabela 4: Delež zaposlenih žensk $v$ celotnem gospodarstvu in $v$ javni upravi po izbranih državah leta 1998

\begin{tabular}{|l|c|c|}
\hline država & $\begin{array}{c}\text { \% zaposlenih žensk med vsemi } \\
\text { zaposlenimi v javni upravi }\end{array}$ & $\begin{array}{c}\text { \% zaposlenih žensk med vsemi } \\
\text { zaposlenimi }\end{array}$ \\
\hline Švedska & 49,1 & 47,7 \\
Slovenija & 48,5 & 47,9 \\
Estonija & 48,4 & 48,2 \\
Francija & 48,1 & 44,5 \\
Slovaška & 47,8 & 45,1 \\
Latvija & 41,3 & 49,1 \\
Finska & 40,6 & 46,6 \\
Švica & 36,6 & 41,8 \\
Avstrija & 36,0 & 42,9 \\
Portugalska & 34,7 & 44,4 \\
Grčija & 32,6 & 36,7 \\
Italija & 32,2 & 35,4 \\
\hline
\end{tabular}

Vir: ILO, 2003.

Strokovna izobrazba je po definiciji formalnopravna kvalifikacija, ki jo je zaposleni pridobil, ko je končal ustrezno izobraževanje na šoli, tečaj ali opravil izpit za pridobitev stopnje izobrazbe ali s priznanjem na podlagi dela. Za vsako stopnjo strokovne izobrazbe mora imeti ustrezni dokument: diplomo, spričevalo, odločbo oz. potrdilo. Strokovna usposobljenost za opravljanje del in nalog pa so splošna in strokovna znanja, praktična usposobljenost in druge lastnosti, ki jih mora imeti oseba, da lahko uspešno opravlja posamezna dela in naloge $v$ podjetju in drugi organizaciji. Stopnje so določene $v$ pravnih in splošnih aktih podjetja in organizacije (SURS, 2000, str. 18).

Deleži žensk $v$ posameznih stopnjah strokovne izobrazbe in usposobljenosti so zelo različni. Najmanjši je pri najvišjih (doktorat, magisterij) in pri nižjih izobrazbenih skupinah (kar je povezano z značilnostmi dela), največji pa pri višji in srednji izobrazbi. Razveseljivo je, da se je v letih 1997-2001 bistveno povečal delež žensk v zgornjih treh razredih strokovne izobrazbe, tako da med visoko, višje in srednje izobraženimi ženske zajemajo več kot polovico vseh zaposlenih.

Stolpca, v katerih so navedeni deleži žensk po stopnjah strokovne usposobljenosti leta 2001 in 1997, tudi kažeta pozitivne usmeritve, vendar so deleži v višjih stopnjah strokovne usposobljenosti še nižji kot pri izobrazbi. Kaj to pomeni? Stopnja strokovne usposobljenosti izvira iz opisa delovnega mesta, na katerem 
oseba dela, $\vee$ nasprotju s stopnjo strokovne izobrazbe, ki je osebna oznaka zaposlenega. Izobražene ženske se torej lahko zaposlijo, vendar težje dobijo delovno mesto, ki bi tej izobrazbi ustrezalo.

Tabela 5: Delež žensk po stopnjah strokovne izobrazbe in usposobljenosti $v$ družbah, podjetjih in organizacijah v Sloveniji 31. 12. 1997 in 31. 12. 2001 (vir: SURS, 2002, str. 231-238; SURS, 1998, str. 219-226)

\begin{tabular}{|l|c|c|c|c|}
\hline \multirow{2}{*}{} & \multicolumn{2}{|c|}{ strokovna izobrazba v \% } & \multicolumn{2}{c|}{ strokovna usposobljenost v \% } \\
\cline { 2 - 5 } & leto 2001 & leto 1997 & leto 2001 & leto 1997 \\
\hline doktorat & 29,1 & 23,8 & 24,0 & 21,4 \\
magisterij & 45,2 & 40,1 & 40,9 & 39,8 \\
visoka - drugi & 54,7 & 50,2 & 49,5 & 44,5 \\
višja & 61,4 & 62,1 & 59,1 & 59,1 \\
srednja & 54,6 & 56,3 & 56,1 & 58,2 \\
nižja in manj & 39,8 & 41,9 & 39,9 & 41,7 \\
\hline skupaj & 47,4 & 48,1 & 47,4 & 48,1 \\
\hline
\end{tabular}

Vir: SURS, 2002, str. 231-238; SURS, 1998, str. 219-226.

Tabela 6: Delež žensk po stopnjah strokovne izobrazbe in usposobljenosti v javni upravi v Sloveniji 31. 12. 1997 in 31. 12. 2001

\begin{tabular}{|l|c|c|c|c|}
\hline \multirow{2}{*}{} & \multicolumn{2}{|c|}{ strokovna izobrazba v \% } & \multicolumn{2}{c|}{ strokovna usposobljenost v \% } \\
\cline { 2 - 5 } & leto 2001 & leto 1997 & leto 2001 & leto 1997 \\
\hline doktorat & 33,7 & 30,4 & 29,7 & 29,7 \\
magisterij & 45,8 & 37,2 & 45,7 & 42,7 \\
visoka - drugi & 56,9 & 53,9 & 54,4 & 50,1 \\
višja & 55,6 & 58,0 & 58,2 & 60,8 \\
srednja & 44,6 & 47,1 & 44,3 & 46,8 \\
nižja in manj & 42,0 & 46,5 & 44,3 & 49,0 \\
\hline skupaj & 49,0 & 49,9 & 49,0 & 49,9 \\
\hline
\end{tabular}

Vir: SURS, 2002, str. 231-238; SURS, 1998, str. 219-226.

V javni upravi so deleži v zgornjih razredih višji kot med vsemi zaposlenimi. To pomeni, da je $\vee$ tej dejavnosti več bolj izobraženih žensk, ki imajo tudi lažji dostop do boljših delovnih mest. Vidimo lahko, da so te razlike pri javni upravi sicer nekoliko manjše kot pri celotnem gospodarstvu, vendar še vedno velike. Organizacija, ki hoče ustrezno izkoristiti svoje potenciale, ne sme dopustiti, da ostajajo kadrovski viri, s katerimi dejansko razpolaga (so torej že zaposleni), premalo izkoriščeni glede na njihovo izobrazbo.

$\checkmark$ spodnji tabeli je prikazana sprememba števila zaposlenih $\vee$ javni upravi $\vee$ štiriletnem obdobju. Od 31. 12. 1997 do 31. 12. 2001 se je število zaposlenih v javni upravi povečalo za 3422, od tega za 1307 žensk (38,2 \%). Število zaposlenih z doktoratom se je povečalo za 61, od tega je 39 \% žensk. Zopet pa vidimo, da so ženske zasedle le 30 $\%$ dodatnih delovnih mest, za katera je bil zahtevan doktorat znanosti. Pri magistrski 


\section{Janko Seljak \\ Razlike $v$ plačah in zaposlovanju med spoloma v dejavnostih javne uprave}

izobrazbi je bilo zaposlenih že 55 \% žensk, in tudi delovnih mest s to stopnjo strokovne usposobljenosti, ki so jih zasedle ženske, je bilo že več kot pol (leta 2001 je bilo v Sloveniji število novih ženskih magistrov in specialistov prvič večje kot število moških - SURS, 2002, str. 134).

Tabela 7: Zaposlene osebe $\mathbf{v}$ družbah, podjetjih in organizacijah $\mathbf{v}$ javni upravi po stopnji strokovne izobrazbe, usposobljenosti in spolu: razlika med 31. 12. 1997 in 31. 12. 2001

\begin{tabular}{|l|c|c|c|c|c|c|c|c|}
\hline & \multicolumn{3}{|c|}{ strokovna izobrazba } & \multicolumn{2}{c|}{ strokovna usposobljenost } & $\begin{array}{c}\% \text { žensk - } \\
\text { izobrazba }\end{array}$ & $\begin{array}{c}\% \text { žensk - } \\
\text { usposob- } \\
\text { ljenost }\end{array}$ \\
\cline { 2 - 10 } & skupaj & moški & ženske & skupaj & moški & ženske & & \\
\hline doktorat & 61 & 37 & 24 & 37 & 26 & 11 & 39,3 & 29,7 \\
magisterij & 331 & 151 & 180 & 115 & 56 & 59 & 54,4 & 51,3 \\
visoka - drugi & 3905 & 1424 & 2481 & 3184 & 1039 & 2145 & 63,5 & 67,4 \\
višja & -193 & 73 & -266 & 27 & 177 & -150 & & \\
srednja & 1098 & 1043 & 55 & 970 & 1064 & -94 & & \\
nižja in manj & -1780 & -613 & -1167 & -911 & -247 & -664 & & \\
\hline skupaj & 3422 & 2115 & 1307 & 3422 & 2115 & 1307 & 38,2 & 38,2 \\
\hline
\end{tabular}

Vir: SURS, 2002, str. 231-238; SURS, 1998, str. 219-226.

Največja skupina dodatnih zaposlenih so tisti z visoko izobrazbo. In prav $\vee$ tej skupini je bilo žensk kar 64 \%. Močno pa se je zmanjšalo število zaposlenih žensk z nižjo stopnjo izobrazbe.

ILO (ILO, 1998) v svojih raziskavah ugotavlja, da je izobrazba žensk danes veliko višja kot $v$ preteklosti in da ženske pomenijo velik del zaposlenih. Vendar pa le redkim ženskam uspe prebiti t. i. "stekleni stolp" (ta izraz vključuje nevidne umetne ovire, ki nastanejo zaradi vedenjskih in organizacijskih predsodkov), ki jih ločuje od vodilnih delovnih mest.

\section{Plače žensk v javni upravi}

Razlike med plačami moških in žensk so že tradicionalno $v$ središču raziskav t. i. "spolne ekonomije" (Blau, Kahn, 1999). Višina plače $\vee$ veliki meri opredeljuje ekonomsko blaginjo zaposlene osebe ter močno vpliva na vrsto odločitev, povezanih s trgom dela in zasebnim življenjem (odločitev za poroko, nosečnost, vpliv na pogajalsko moč $\checkmark$ družini in tudi določanje sorazmernega statusa $v$ družini).

Analiza diskriminacije pri nagrajevanju naj bi odkrila razlike $v$ plačilu, ki niso rezultat produktivnosti oz. količine in kakovosti opravljenega dela, ampak spola, barve kože ali drugih značilnosti delavca. Raziskave so pokazale, da sta za razlike v plačah moških in žensk $v$ glavnem dve skupini razlogov:

- prvi je poklicna delitev: moški običajno opravljajo bolje plačana delovna mesta kot ženske;

- drugi je količina in kakovost človeškega kapitala: moški imajo boljše možnosti inve- 
stiranja v človeški kapital in s tem v boljšo kakovost dela. Glavni razlog za to naj bi bil, da se delovna doba žensk pogosto prekine za nekaj let (zaradi nosečnosti).

Kljub upoštevanju teh dveh vplivov ostaja velik del razlik med plačami moških in žensk običajno "nepojasnjen", pripiše pa se diskriminaciji.

Raziskave $\vee$ razvitih državah so pokazale, da so razlike med plačami moških in žensk, zaposlenih v javni upravi, manjše kot pa med vsemi zaposlenimi oz. v zasebnem sektorju (npr. Zetterberg, 1994; Hoffnar, Green, 1996). Ali je tudi v Sloveniji tako? Podatki kažejo (tabela 2), da so plače $\vee$ javni upravi v povprečju precej višje kot med vsemi zaposlenimi (leta 2000 za 23,4 \%). V spodnji tabeli (Tabela 8) so navedeni indeksi, ki nam kažejo, za koliko odstotkov plače $v$ javni upravi $v$ posameznem razredu strokovne usposobljenosti presegajo povprečne.

Tabela 8: Indeksi povprečnih plač v javni upravi (osnova je povprečna plača) in struktura zaposlenih $\mathbf{v}$ javni upravi po spolu

\begin{tabular}{|l|c|c|c|c|}
\hline \multirow{2}{*}{} & \multicolumn{2}{|c|}{ indeks povprečna plača = 100 } & \multicolumn{2}{c|}{$\begin{array}{c}\text { struktura zaposlenih } \\
\text { v javni upravi v \% }\end{array}$} \\
\cline { 2 - 5 } & moški & ženske & moški & ženske \\
\hline doktorat & 150,3 & 170,5 & 0,2 & 0,1 \\
magisterij & 103,3 & 111,0 & 0,8 & 0,7 \\
visoka skupaj & 91,4 & 107,6 & 24,8 & 30,8 \\
višja & 84,4 & 82,9 & 11,5 & 16,7 \\
srednja & 102,1 & 89,4 & 51,6 & 42,6 \\
nižja in manj & 102,2 & 105,3 & 11,1 & 9,2 \\
\hline skupaj & 125,6 & 121,0 & 100,0 & 100,0 \\
\hline
\end{tabular}

Vir: SURS, 2002, str. 231-260.

Pri primerjavi povprečnih brutoplač lahko ugotovimo različna razmerja znotraj posameznih skupin strokovnih usposobljenosti. Moški, ki so delali na delovnih mestih, za katera se zahteva doktorat, so imeli v javni upravi za 50,3 \% večje plače kot v celotnem gospodarstvu, ženske pa kar za 70,5 \%. Pri magisteriju so razlike že manjše, vendar so plače $v$ javni upravi višje tako pri moških kot pri ženskah. Razlika je pri skupnih podatkih za visoko izobrazbo: plače $v$ javni upravi so za ženske višje kot za vse zaposlene, za moške pa nižje.

$\checkmark$ javni upravi so imele nižjo plačo od povprečja vseh zaposlenih le ženske z visoko in srednjo izobrazbo. Vendar ta skupina zajema kar $58 \%$ zaposlenih žensk $\vee$ tej dejavnosti.

$\mathrm{Na}$ razlike med plačami lahko bistveno vplivajo tudi drugi dejavniki. Machin in Puhani (2003, str. 393-400) sta v svoji analizi ugotovila, da področje pridobljene diplome bistveno vpliva na višino plače. Avtorja ugotavljata, da so ženske veliko bolj zastopane na tistih smereh študija, kjer so plače nižje: študij jezikov, humanistika, umetnost, izobraževanje. Izrazito večji delež moških pa je na področjih, kjer so plače višje (tehnika, fizika, matematika). Analiza za Nemčijo in Veliko Britanijo je pokazala, da z vplivom 


\section{Janko Seljak \\ Razlike $v$ plačah in zaposlovanju med spoloma v dejavnostih javne uprave}

področja diplome lahko pojasnimo 2-4 \% višje plače moških. Na razliko med plačami med moškimi in ženskami tako vpliva že sama odločitev za smer študija.

To lahko pojasnjuje zgornji podatek, da moški z visoko izobrazbo, zaposleni v javni upravi, dosegajo le 91 \% povprečja vseh zaposlenih, ženske pa 107 \%. Moški v drugih dejavnostih so $\vee$ glavnem diplomirali na smereh, ki spadajo $\vee$ bolj donosne (tehnika, računalništvo, medicina, ekonomija) in so zato njihove plače višje. Ženske so $v$ pretežni meri $v$ drugih dejavnostih, kjer so plače nižje (izobraževanje, socialne službe, jeziki). Zato so tudi povprečne plače vseh zaposlenih nižje.

Tabela 9: Povprečna mesečna brutoplača za zaposleno osebo v družbah, podjetjih in organizacijah po stopnjah strokovne usposobljenosti 2000

\begin{tabular}{|l|c|c|c|c|c|c|c|}
\hline \multirow{2}{*}{$\begin{array}{l}\text { strokovna } \\
\text { usposobljenost }\end{array}$} & \multicolumn{2}{|c|}{$\begin{array}{c}\text { vse dejavnosti } \\
\text { plača v 1000 SIT }\end{array}$} & \multicolumn{2}{c|}{$\begin{array}{c}\text { javna uprava } \\
\text { plača v 1000 SIT }\end{array}$} & \multicolumn{2}{|c|}{$\begin{array}{c}\text { indeks } \\
\text { moški = 100 }\end{array}$} & $\begin{array}{c}\text { razlika } \\
\text { (\%) }\end{array}$ \\
\cline { 2 - 8 } & moški & ženske & moški & ženske & $\begin{array}{c}\text { vse } \\
\text { dejavnosti }\end{array}$ & $\begin{array}{c}\text { javna } \\
\text { uprava }\end{array}$ & \\
\hline doktorat & 531,0 & 456,2 & 797,9 & 778,0 & 85,9 & 97,5 & 11,6 \\
magisterij & 514,1 & 427,6 & 530,9 & 474,6 & 83,2 & 89,4 & 6,2 \\
visoka skupaj & 434,1 & 344,2 & 396,8 & 370,4 & 79,3 & 93,3 & 14,1 \\
višja & 282,1 & 246,8 & 238 & 204,6 & 87,5 & 86,0 & $-1,5$ \\
srednja & 205,1 & 181,6 & 209,4 & 162,3 & 88,5 & 77,5 & $-11,0$ \\
nižja in manj & 141,8 & 113,4 & 145,0 & 119,4 & 79,9 & 82,4 & 2,4 \\
\hline skupaj & 215,3 & 188,9 & 270,4 & 228,5 & 87,7 & 84,5 & $-3,2$ \\
\hline
\end{tabular}

Vir: SURS, 2002, str. 258-260.

Ženske so imele nižje plače od moških v obeh opazovanih skupinah. V celotnem gospodarstvu so se najbolj približale plačam moških ženske, ki delajo na delovnih mestih, za katera se zahteva srednja in višja izobrazba, v javni upravi pa daleč najbolj skupine iz zgornjih razredov: pri doktoratu so ženske že skoraj dosegle brutoplače moških. Relativno najniže plače imajo $v$ javni upravi ženske s srednjo izobrazbo (22 \% manj kot moški).

Med vsemi zaposlenimi velikih razlik med skupinami strokovne usposobljenosti ni, najmanjše razlike med moškimi in ženskami so pri srednji izobrazbi in največje pri visoki. $\vee$ javni upravi so razlike $\vee$ višjih dohodkovnih razredih (visoka, magisterij, doktorat) veliko manjše, kot pa $\vee$ nižjih. Pomembno je tudi, da so razlike največje prav $\vee$ skupini, ki je številčno največja (v skupini s srednjo strokovno usposobljenostjo je kar $43 \%$ vseh zaposlenih v javni upravi).

Podobne tendence kot $\vee$ Sloveniji $\vee$ javni upravi so bile odkrite tudi $\vee$ nekaterih drugih raziskavah. Podatki namreč kažejo (npr. Eurostat, 2003), da se razlike v povprečnih plačah moških in žensk manjšajo. To je predvsem posledica tega, da je vedno več žensk na bolje plačanih mestih, kar zmanjšuje razlike med povprečnimi plačami moških in žensk. Vendar pa primerjave pokažejo, da so se zmanjšale razlike le $v$ zgornjih plačilnih razredih, medtem ko večina žensk ostaja ujeta $v$ slabo plačanih "ženskih poklicih" z relativno nizkim statusom (Bruegel, Perrons, 2002 v ILO, 2003, str. 52). 
Zaradi različnih zakonodaj, zbiranja podatkov in definicij posameznih pojmov je kvaliteta primerjav plač med različnimi državami nekoliko manjša. $\vee$ tem članku bodo $\vee$ primerjavi uporabljeni podatki ILO, ki edina prikazuje podatke o plačah po enotnih definicijah. Primerljivi podatki o plačah $v$ javni upravi so na voljo le za manjšo skupino držav. ${ }^{7}$ Vzroki razlik med povprečnimi plačami moških in žensk se med državami lahko razlikujejo in so rezultat:

- razlike pri investicijah $\vee$ človeški kapital: investicije $\vee$ izobraževanje, usposabljanje, mobilnost in iskanje dela so pri ženskah običajno nižje kot pri moških;

- horizontale poklicne segregacije: "moški" poklici imajo običajno višje plače;

- vertikalne poklicne segregacije: ženske običajno zasedajo nižje položaje znotraj iste poklicne skupine;

- nujnosti usklajevanja odgovornosti v okviru delovnega mesta in družine;

- delovnih izkušenj: ženske pogosteje prekinejo delovno razmerje;

- znanja: pogosto primanjkuje tudi informacij, na osnovi katerih bi lahko ženske spoznale svoje pravice in si jih na ustrezen način izborile.

Tabela 10: Plače žensk v vseh dejavnostih in v javni upravi po izbranih državah

\begin{tabular}{|l|c|c|c|}
\hline \multirow{2}{*}{ država } & \multicolumn{2}{|c|}{ indeksi (moški = 100) } & \multirow{2}{*}{ leto } \\
\cline { 2 - 3 } & javna uprava & javna uprava & \\
\hline Latvija & 100,4 & 80,2 & 2001 \\
Švedska & 94,2 & 88,4 & 2001 \\
Litva & 90,5 & 81,9 & 1999 \\
Portugalska & 86,5 & $95,0^{*}$ & 1998 \\
Slovenija & 85,0 & 88,0 & 2000 \\
Madžarska & 83,2 & 81,3 & 2001 \\
Nizozemska & 82,6 & 78,2 & 2000 \\
Avstrija & 81,2 & $79,0^{*}$ & 1999 \\
Švica & 81,2 & $\ldots$ & 2000 \\
Velika Britanija & 78,5 & 82,1 & 2001 \\
Finska & 77,7 & $82,0^{*}$ & 1999 \\
\hline
\end{tabular}

Vir: ILO, 2003; * EUROSTAT, 2003.

V Latviji imajo $\vee$ javni upravi ženske $\vee$ povprečju višje plače kot moški. Visoko vrednost indeksa imata tudi Švedska in Litva. Mesto Švedske v vrhu držav z najmanjšimi razlikami ne preseneča. Tudi druge analize razlik plač med moškimi in ženskami v razvitih državah so pokazale (npr. Martin, Gunnel, 1991) da so na Švedskem razlike med plačami moških in žensk najmanjše.

Pri vzhodnoevropskih državah (Latvija, Litva, tudi Slovenija) so tudi drugi avtorji ugotovili podobne tendence. ILO (2003, str. 53) navaja, da se v nekaterih

7 Podobno ugotavljajo tudi drugi raziskovalci tega področja. Mihelčič (2003, str. 64) ugotavlja, da je pri poskusih zbiranja primerljivih podatkov (o plačah $v$ javnem sektorju) naletel na skoraj nepremostljive težave, tako pri iskanju na straneh svetovnega spleta, kot pri veleposlaništvih tujih držav pri nas in naše države $v$ nekaterih tujih državah. 


\section{Janko Seljak \\ Razlike $v$ plačah in zaposlovanju med spoloma v dejavnostih javne uprave}

vzhodnoevropskih državah razlika med povprečnimi plačami moških in žensk zmanjšuje in da je $v$ nekaterih že dosegla ravni moških. Tudi Newell in Reilly (2001, str. 287-304) za "države $v$ tranziciji" ugotavljata, da so se razlike med plačami moških in žensk $v$ obdobju tranzicije manjšale.

Če primerjamo podatke za javno upravo in za vse zaposlene, lahko ugotovimo, da je $\vee$ večini držav, za katero so na voljo podatki, razlika med plačami moških in žensk manjša $\vee$ javni upravi kot pa med vsemi zaposlenimi. Tudi druge raziskave $\vee$ razvitih državah so pokazale, da so razlike med plačami moških in žensk $v$ javnem sektorju manjše kot v privatnem (npr. za Švedsko: Zetterberg, 1994; za ZDA: Hoffnar, Green, 1996). Izjema so le Velika Britanija, Portugalska in Slovenija.

\section{Zaključek}

Med zaposlenimi v Sloveniji je bilo konec leta 200147 \% žensk, med zaposlenimi v javni upravi pa celo $49 \%$. Število zaposlenih žensk $v$ javni upravi počasi narašča in je preseglo 22.000. Izobrazba te kategorije zaposlenih se je $\vee$ zadnjih štirih letih izboljšala, tako da je bilo leta 2001 med vsemi doktorji znanosti v javni upravi 34 \%, med magistri $46 \%$ in med delavci z visoko izobrazbo $55 \%$ žensk.

Dodatno informacijo o delitvi vlog med spoloma nam daje primerjava med strokovno izobrazbo in strokovno usposobljenostjo. Strokovna izobrazba je lastnost osebe, medtem ko stopnja strokovne usposobljenosti izvira iz opisa delovnega mesta. Iz primerjave teh dveh podatkov lahko ugotovimo, ali je delež zaposlenih žensk z neko stopnjo izobrazbe (npr. doktoratom) enak deležu žensk, ki zasedajo delovna mesta, na katerih se zahteva ta vrsta strokovne usposobljenosti (npr. doktorat). Tako je bilo leta 2001 med vsemi zaposlenimi v Sloveniji z doktoratom 29 \% žensk, le 24 \% delovnih mest, za katera se zahteva doktorat, pa so zasedale ženske. Podobne razmere so tudi v javni upravi, le da so deleži nekoliko višji (34 : 30 \%). To pomeni, da ženske z visoko izobrazbo (magisterijem ali doktoratom) dobijo zaposlitev, težje pa dobijo ustrezno delovno mesto. Kljub temu pa je analiza pokazala, da se je stanje $\vee$ zadnjih štirih letih pri mestih, "ki niso čisto na vrhu" (visoka usposobljenost, magisterij), že bistveno izboljšalo. Nekoliko problematična so samo še mesta na vrhu "steklenega stolpa".

Tiste posameznice, ki so že uspele priti v vrh "steklenega stolp", pa imajo v javni upravi, v primerjavi z drugimi zaposlenimi ženskami, privilegiran položaj. Analiza brutoplač je pokazala, da so ženske z visoko izobrazbo (vključno z doktoratom in magisterijem) nedvomno manj diskriminirane od svojih kolegic $\vee$ drugih dejavnostih. Imajo več možnosti, da zasedejo boljša delovna mesta, njihove povprečne plače so bistveno višje od njihovih kolegic $\vee$ drugih sektorjih (za $8 \% \vee$ skupini 'visoka strokovna usposobljenost', v skupini 'doktorat' celo $71 \%$ ). V popolnoma drugačnem položaju so ženske $v$ javni upravi s srednjo in višjo izobrazbo: njihove povprečne plače so bile nižje za 17 oz. $11 \%$ od povprečja za vse zaposlene ženske $\vee$ teh razredih strokovne usposobljenosti in 14 oz. 22 \% od plač moških, zaposlenih v javni upravi.

Ženske, zaposlene $v$ slovenski javni upravi z visoko izobrazbo in višjimi brutoplačami, so nedvomno manj diskriminirane kot pa tiste iz nižjih dohodkovnih skupin. 
Takšne tendence se kažejo tudi v drugih razvitih državah. Nedvomno imajo izobražene ženske $v$ javni upravi lažje delo pri zavzemanju za svoje pravice. Zaposlene z nižjimi stopnjami strokovne usposobljenosti se premalo zavzemajo za svoje pravice, so o njih premalo informirane in so verjetno še vedno ujete v "ženske poklice" z nižjim statusom in plačami (tajnice, administratorke ipd.). $V$ javni upravi izobrazba bistveno prispeva $k$ manjšanju razlik $v$ plačah.

Delež žensk med vsemi zaposlenimi v Sloveniji je med najvišjimi na svetu, v javni upravi pa je že nad 49 \%. To uvršča Slovenijo v skupino držav (Švedska, Estonija, Francija) z največjim deležem zaposlenih žensk. Tudi razlike med plačami moških in žensk so v Sloveniji razmeroma nizke. Ženske so imele leta 2000 v povprečju $12 \%$ nižje plače od moških (kar je približno toliko kot $\vee$ Švedski). Preseneča pa razmeroma velika razlika med plačami moških in žensk $v$ javni upravi: $\vee$ tej dejavnosti so imele ženske kar $15 \%$ nižje plače od moških. $V$ večini primerjanih držav je bilo prav nasprotno: razlike $\vee$ plačah so bile $\vee$ javni upravi manjše kot $\vee$ drugih dejavnostih. Država bi nedvomno morala $\vee$ dejavnosti, kjer je sama delodajalec, zagotoviti tudi primerljive plače zaposlenim ne glede na spol. Analiza je pokazala, da je treba $\vee$ javni upravi zmanjšati predvsem razlike $v$ plačah zaposlenih moških in žensk $s$ srednjo in višjo strokovno usposobljenostjo. $\vee$ tej skupini je $30 \%$ vseh zaposlenih žensk.

Analiza podatkov za Slovenijo je izvedena tako, da jih je mogoče primerjati z drugimi državami. Le tako lahko (ob pomanjkanju absolutnih kriterijev) realno ovrednotimo stanje na nekem področju $\vee$ posamezni državi kot dela širšega kulturno-gospodarskopolitičnega območja. To je možno le na osnovi preučevanja splošnih značilnosti opazovanega pojava. Analiza je nedvomno pokazala, katere skupine zaposlenih so v javni upravi s stališča spolne diskriminacije najbolj problematične. Raziskave o razlikah znotraj teh skupin, na osnovi katerih bi lahko sledili ustrezni ukrepi, je treba izvesti znotraj posameznih ministrstev oz. organizacijskih enot v okviru posameznih ministrstev. Kje konkretno je spolna diskriminacija največja, je torej možno ugotoviti samo na osnovi primerjave večjega števila kazalcev, ki kažejo individualne značilnosti zaposlenih na delovnih mestih enake zahtevnosti. Namen analize $v$ tem članku je bil pokazati splošne značilnosti in opozoriti na najbolj problematične skupine $\vee$ javni upravi. Na tej ravni bi analiza posamičnih podatkov dala slabše rezultate, saj bi imele individualne lastnosti zaposlenih oz. delovnih mest prevelik vpliv. Poleg tega nastopajo na tej ravni analize problemi, povezani z varstvom podatkov in (ob uporabi razgovora kot sredstva zbiranja podatkov) subjektivnimi ocenami zbiralca podatkov. Zato je za oceno splošnega stanja na posameznem področju najprimernejša analiza agregatnih podatkov, ki so zbrani v okviru najboljšega (nekateri bi dejali, da najmanj slabega) sistema zbiranja podatkov $\vee$ Sloveniji (Statističnega urada RS), ki je skoraj v celoti usklajen z mednarodnimi standardi. 


\section{Janko Seljak \\ Razlike v plačah in zaposlovanju med spoloma $v$ dejavnostih javne uprave}

\section{Literatura:}

- Blau, F. D., Kahn, M. L. (1999): Analyzing the gender pay gap, The Quarterly Review of Economics and Finance, University of Illinois, let. 39, št. 5, str. 625-646.

- Hazl, V. (2002): Smo Slovenke na trgu delovne sile enakopravne?, Pospeševalni center za malo gospodarstvo, Ljubljana.

- Hoffnar, E., Green, M. (1996): Gender Discrimination in Public and Private Sectors: A Sample Selectivity Approach, Journal of Socio-Economics, let. 25, št. 1, str. 105-114.

- Machin, S., Puhani, P. A. (2003): Subject of degree and the gender wage differential: evidence from the UK and Germany, Economics Letters, let. 79, št. 3, str. 393-400.

- Martin, J. A., Gunnel, H. (1991): Swedish and American Approaches to improving working Woman Status: Context and Comparable Worth, International Journal of Public Administration; New York.

- Mihelčič, M. (2003): Plače v javnem sektorju Slovenije v luči primerjav z drugimi državami, v Turk, I. (ur.): Simpozij o sodobnih metodah v računovodstvu, financah in reviziji, Ljubljana:

Zveza ekonomistov Slovenije, 2003, str. 55-68

- Newell, A., Reilly, B. (2001): The gender pay gap in the transition from communism: some empirical evidence, Economic Systems, let. 25, št. 4, Brighton, str. 287-304.

- Seljak, J. (2000): Analiza števila in strukture zaposlenih v javni upravi, obrambi in obveznem socialnem zavarovanju v Sloveniji, Javna uprava, let. 36., št. 4, Ljubljana 2000, str. 481-496.

- Woodward, E. A. (2002).: Going for Gender Balance, Council of Europe, str. 124.

- Zetterberg, J. (1994): Effects of changed wage setting conditions on male female wage differentials, Public Administration Quarterly: Randallstown, jesen 1994.

\section{Viri:}

- European industrial relations observatory (2003): EIRO - online, EIRO, "http://www.eire.eurofound.ie".

- Eurostat (2003): "Statistical datebase", Eurostat, "http://www.europa.eu.int/comm/eurostat".

- International Labour Organization (1998): World of Work, št. 23; International Labour

Organization, Geneve.

- International Labour Organization (2003): "Statistical database", ILO,

"http://labstat.ilo.org/cgi-bin/broker.exe".

- International Labour Organization (2003a): Time for Equality at Work: Global Report under the Follow-up to the ILO Declaration of Fundamental Principles and Rights at Work, International Labour Office, Geneve.

- Statistični urad RS (1996): Statistični letopis 1996, Statistični urad RS, Ljubljana.

- Statistični urad RS (1998): Statistični letopis 1998, Statistični urad RS, Ljubljana.

- Statistični urad RS (1999): Statistični letopis 1999, Statistični urad RS, Ljubljana.

- Statistični urad RS (2000): Statistični letopis 2000, Statistični urad RS, Ljubljana.

- Statistični urad RS (2001): Statistični letopis 2001, Statistični urad RS, Ljubljana.

- Statistični urad RS (2002): Statistični letopis 2002, Statistični urad RS, Ljubljana.

- Zakon o delovnih razmerjih (Uradni list RS, št. 14/90, 5/91, 29/92, 71/93, 2/94, 12/99, 101/99, 42/02). 
Janko Seljak je doktor ekonomskih znanosti. Po diplomi je bil zaposlen na Statističnem uradu Republike Slovenije, od leta 1993 pa na Fakulteti za upravo Univerze v Ljubljani predava statistiko. Aktivno je sodeloval pri projektih s področja uravnoteženega regionalnega in strukturnega razvoja, varstva okolja, zaposlenosti v javnem sektorju, ekonomike $v$ javnem sektorju, davkov in merjenja kakovosti pedagoškega dela. Je avtor številnih učbenikov s področja statistike.

\section{SUMMARY \\ Wages and Gender Differences between the Employees in the Activities of Public Administration}

Key words: public administration, public sector, wages, gender pay gap, sex discrimination, gender

The main purpose of the analysis presented in this article is to find out whether there exist differences in the treatment of men and women in public administration, defence and compulsory social security (and if so, how they are demonstrated), or whether we can, on the basis of the used indicators, ascertain a lower degree of discrimination against women employed in public administration in comparison to the entire economy. The state should be the first to guarantee respect of the Constitution and the laws, which incontestably guarantee freedom of work, free choice of employment, and access to any position of employment under the same conditions for all citizens. Therefore, the state should also guarantee equal access to jobs and equal remuneration for employments in public administration, where it acts as the employer. In accordance with this task, the analysis focused on two areas, which also have a considerable impact on all other areas. First, the data on the employee structure according to professional attainment and professional skills show the share of women among the employees in individual groups, as well as the changes which occurred in the last four years (the right to equal access to any position of employment in the public administration). In the second part of the thesis, this analysis was supplemented by a demonstration of the wage ratios between men and women (the right to equal remuneration for work of the same value).

At the end of 2001, there were $47 \%$ of women among the employed persons in Slovenia, and as much as $49 \%$ among the employed persons in the public administration. The number of the employed women in the public administration has been slowly increasing and has reached the number of 22.262. The education of this category of employees has been improving over the last four years, thus in 2001 there were $34 \%$ of women among all Doctors of Science in the public administration, $46 \%$ among all Masters, and $55 \%$ among the employees with university education. 


\section{Janko Seljak}

Razlike v plačah in zaposlovanju med spoloma

v dejavnostih javne uprave

Additional information on the division of roles between the sexes is obtained by a comparison between professional attainment and professional skills. Professional attainment is a quality of a person, while the degree of professional skills arises from the job description. By comparing these two data, we can find out whether the share of employed women with a certain degree of education (e.g. doctor's degree) corresponds to the share of women occupying the positions, which require this type of professional skills (e.g. doctor's degree). Thus, in 2001 there were $29 \%$ of women among all employees with a doctor's degree, with only $24 \%$ of positions, which require a doctor's degree, being held by women. A similar situation also exists in the public administration, with only the percentages being a bit higher (34\%:30\%). This means that women with university education (a master's degree or a doctor's degree) do get jobs, but to a much smaller extent do they get suitable jobs. Nevertheless, the analysis has shown that the situation with regard to the positions "which are not at the very top" (university level of professional skills, master's degree) substantially improved in the last four years. Only the positions at the top of the "glass tower" remain somewhat problematic.

However, those individual women, who have already managed to reach the top of the "glass tower", have a privileged position in the public administration in comparison to the other employed women. The analysis of gross wages has shown that women with university education (including a doctor's degree and a master's degree) are undoubtedly less discriminated against than their colleagues in the other activities. They have more possibilities to occupy better positions, their average wages substantially exceed the wages of their colleagues in the other sectors (by $8 \%$ in the group 'university level of professional skills, and by as much as $71 \%$ in the group 'doctor's degree'). The situation of women in the public administration with secondary or higher (non-university) education is completely different: their average wages were by $17 \%$ and $11 \%$, respectively, lower than the average for all employed women in these categories of professional skills, and by $14 \%$ and $22 \%$, respectively, lower than the wages of men employed in the public administration.

Women employed in the Slovene public administration with university education and higher gross wages are undoubtedly less discriminated against than the women from lower income groups. Such tendencies are also present in the other developed countries. It is undoubtedly easier for the educated women in public administration to stand up for their rights. The employed women with lower levels of professional skills do not sufficiently stand up for their rights, they are not sufficiently informed about them, and are probably still caught in the socalled "female" occupations with a lower status and lower wages (secretaries, administrators, etc.). In the public administration, education considerably contributes to the reduction of wage differences.

In Slovenia, the share of women among all employees is among the highest in the world. In public administration, this share has already exceeded $49 \%$. This 
places Slovenia among the countries (Sweden, Estonia, France) with the highest percentage of employed women. Also the pay gap between men and women in Slovenia is relatively small. In 2000, women's wages were on average by $12 \%$ lower than men's wages (which is approximately the situation in Sweden). We are, however, surprised at the large gap between wages of men and women in the public administration: in this activity, women's wages were by as much as 15 $\%$ lower than men's wages. In the majority of the countries taken for comparison, the situation was exactly the opposite: the pay gap in the public administration was smaller than in the other activities. In the activity, where it acts as the employer, the state should ensure comparable wages to the employees regardless of their sex. The analysis has shown that in the public administration it is especially necessary to reduce the differences between the wages in the group with secondary and non-university level of professional skills, which represents $30 \%$ of all employed women. 